\title{
Bacterial metabolism of algal extracellular carbon*
}

\author{
Michael F. Coveney ${ }^{1} \&$ Robert G. Wetzel ${ }^{2}$ \\ Michigan State University, W. K. Kellogg Biological Station, Hickory Corners, MI 49060; ${ }^{1}$ Water \\ Resources Department, St. Johns River Water Management District, P.O. Box 1429, Palatka, FL \\ 32078-1429, U.S.A.; ${ }^{2}$ The University of Michigan, Department of Biology, Ann Arbor, MI 48109, \\ U.S.A.
}

Key words: bacteria, phytoplankton, EOC, respiration, mineralization, substrate

\begin{abstract}
Measurements of microbial utilization of extracellular organic carbon (EOC) released by phytoplankton commonly consider only EOC fractions subject to rapid uptake. Questions remain whether other EOC fractions are metabolized, what portion is labile, and with what assimilation efficiency this carbon substrate is utilized. ${ }^{14} \mathrm{C}$-EOC was prepared by incubation of the natural mixed planktonic community from an oligotrophic lake with $\mathrm{H}^{14} \mathrm{CO}_{3}$ in the light. ${ }^{14} \mathrm{C}-\mathrm{EOC}$ which was not rapidly removed by heterotrophs remained in solution and was isolated by filtration. This residual EOC was inoculated with lake microheterotrophs in laboratory microcosms, and utilization kinetics were determined through long-term assays of cumulative ${ }^{14} \mathrm{CO}_{2}$ production. Time-courses for ${ }^{14} \mathrm{CO}_{2}$ production were consistent for all assays and were well described by a deterministic mixed-order degradation model. On twelve sampling occasions, from $29 \%$ to $76 \%$ of residual ${ }^{14} \mathrm{C}$-EOC was labile to further metabolism by lake heterotrophs. First-order rate constants for EOC utilization showed a mode of 0.05 to 0.15 per day. From $33 \%$ to $78 \%$ of gross ${ }^{14} \mathrm{C}$-EOC uptake was respired (mean $50 \%$ ), indicating appreciable return of algal EOC to the pelagic food web as microbial biomass.
\end{abstract}

\section{Introduction}

Release of extracellular organic carbon (EOC) by phytoplankton can be an important source of labile organic substrate for bacterioplankton (Azam et al., 1983; Riemann \& Søndergaard, 1984b). Extracellular products were estimated to support $24-45 \%$ of summer epilimnetic bacterial production in an oligotrophic lake (Bell \& Kuparinen, 1984), 50\% in the Baltic Sea (Larsson \& Hagstrom, 1982) and $14 \%$ in eutrophic Lake Mendota (Brock \& Clyne, 1984). Bacterial utilization of this material is commonly measured by differential filtration (Coveney, 1982; Wolter, 1982; Riemann et al., 1982; Kato \& Stabel, 1984; Lovell \& Konopka, 1985), where ${ }^{14} \mathrm{C}$ in bacterialsized particles is assayed after incubation of lake water with $\mathrm{H}^{14} \mathrm{CO}_{3}$ tracer. These size-fractionation techniques measure rapid bacterial uptake of algal EOC which occurs during the labelling incubation, but any slower metabolism of other EOC fractions is neglected.

There is evidence, primarily from marine studies, that EOC can accumulate during photosynthetic ${ }^{14} \mathrm{Clabelling}$ of natural mixed planktonic communities and subsequently be utilized by bac-

\footnotetext{
* Contribution No. 596, W. K. Kellogg Biological Station, Michigan State University.
} 
teria (Iturriaga \& Hoppe, 1977; Chrost \& Faust, 1983; Iturriaga \& Zsolnay, 1983; Berman \& Kaplan, 1984). Gross uptake rates from $1 \%$ to $18 \%$ of residual EOC per hour were reported, with respiration from $19 \%$ to $93 \%$ of uptake. If residual algal EOC is in fact labile, then sizefractionation studies underestimate overall flux of algal carbon to bacterioplankton.

We addressed the question of long-term metabolism of algal EOC by measuring bacterial utilization of residual ${ }^{14} \mathrm{C}$-labelled EOC after incubation of the natural mixed community with $\mathrm{H}^{14} \mathrm{CO}_{3}$. Assays of EOC utilization were performed at in situ temperature in laboratory microcosms with inocula of lake heterotrophs. Timecourses for mineralization of residual ${ }^{14} \mathrm{C}$-EOC were determined, along with ${ }^{14} \mathrm{C}$ assimilated at the termination of each time-course. We applied an empirical model for degradation of carbon substrates to time-course data to estimate the rate and efficiency of bacterial EOC utilization.

\section{Materials and methods}

\section{Sampling}

EOC utilization was assayed on 12 occasions during April-November 1984 with planktonic communities in Lawrence Lake, an oligotrophic hardwater lake in southwestern Michigan (Wetzel, 1983). An integrated epilimnetic water sample was taken at a central pelagic station with a 4-m Van Dorn-type sampler and transported to the laboratory.

\section{Assay for utilization of residual EOC}

EOC was labelled by incubation of lake water with 2.0 to $2.4 \mu \mathrm{Ci} / \mathrm{ml}(75-88 \mathrm{kBq} / \mathrm{ml})$ for 6 to $8.5 \mathrm{~h}$ at in situ temperature and $160 \mu$ Einsteins $\mathrm{m}^{-2} \mathrm{~s}^{-1}$ photosynthetically active radiation. Long incubation periods were chosen to decrease ${ }^{14} \mathrm{C} /{ }^{12} \mathrm{C}$ disequilibrium effects on EOC labelling (Storch \& Saunders, 1978; Jensen et al., 1985). After incubation the water was filtered $(0.2-\mu \mathrm{m}$ pore-size cellulose acetate, $33 \mathrm{kPa}$ pressure differential), and the filtrate was acidified to $\mathrm{pH}$ 3.0-3.5 and sparged with air $90 \mathrm{~min}$, including
5 min with pure $\mathrm{CO}_{2}$. This procedure was shown to remove all inorganic ${ }^{14} \mathrm{C}$. The residual ${ }^{14} \mathrm{C}$-EOC substrate was prepared by addition of $5 \mathrm{mM}$ morpholinopropane sulfonic acid (MOPS) buffer to the filtrate, followed by $\mathrm{pH}$ adjustment to 7.0 (necessary for radiorespirometric assay) and final sterile filtration.

The assay for long-term utilization of EOC was initiated $24-48 \mathrm{~h}$ after preparation of ${ }^{14} \mathrm{C}$-EOC substrate. We prepared an inoculum of lake microheterotrophs by gentle filtration of lake water through a $3-\mu \mathrm{m}$ pore-size Nuclepore membrane and centrifugation of the filtrate $\left(15 \mathrm{~min}, 10^{4} \mathrm{~g}\right)$ to concentrate cells $8 \mathrm{x}-10 \mathrm{x}$. Cumulative, nondestructive measurements of ${ }^{14} \mathrm{CO}_{2}$ release were made in replicate $(n=3$ to 8$)$ double-vial microcosms, the assembly of which has been described in detail (Type C in Coveney \& Wetzel, 1984). $5.00 \mathrm{ml}{ }^{14} \mathrm{C}$-EOC substrate and $0.50 \mathrm{ml}$ inoculum were placed in a sterile glass liquid scintillation vial and were purged continuously with $\mathrm{CO}_{2}$-free air. A sterile inner vial containing a Whatman GF/C glass fiber wick impregnated with $\mathrm{NaOH}$ and scintillation fluors was added, and the outer vial was sealed using sterile teflon over buna rubber cap liners. Initial bacterial cell counts after inoculation $\left(0.5\right.$ to $2.2 \times 10^{6}$ cells per $\left.\mathrm{ml}\right)$ ranged from 16 to $51 \%$ of lakewater densities. Blank vials received substrate and either no inoculum or inoculum plus $0.2 \mathrm{mM} \mathrm{HgCl} 2$. Respiratory ${ }^{14} \mathrm{CO}_{2}$ diffused into the gas phase and was trapped on the inner wick. This ${ }^{14} \mathrm{C}$ was assayed at intervals in a liquid scintillation counter at $40-50 \%$ efficiency, which was determined by injection of a $\mathrm{Na}_{2}{ }^{14} \mathrm{CO}_{3}$ standard into replicate vials. All vials were incubated with rotary shaking $(100-150 \mathrm{rpm})$ in the dark at lake temperature between assay occasions.

Respirometric measurements were terminated when ${ }^{14} \mathrm{CO}_{2}$ evolution slowed. Vials were opened, and the lake water was filtered $(0.2-\mu \mathrm{m}$ pore-size $)$ for determination of assimilated (particulate) ${ }^{14} \mathrm{C}$ by liquid scintillation counting. Significant wall growth occurred, and this attached portion of assimilated ${ }^{14} \mathrm{C}$ was measured by addition of tissue solubilizer (Soluene 350, Packard Instrument Co.) to the empty vials, digestion at $40{ }^{\circ} \mathrm{C}$, 
and addition of fluor solution. Neither sterile blank vials nor $\mathrm{HgCl}_{2}$-poisoned vials showed evolution of ${ }^{14} \mathrm{CO}_{2}$. Slight particulate ${ }^{14} \mathrm{C}$ and significant attached ${ }^{14} \mathrm{C}$ blank values were common, and these were subtracted from assay values.

\section{Mineralization models}

We analyzed time-course data for respiration of ${ }^{14} \mathrm{C}$-EOC using mineralization models developed by Brunner \& Focht (1984) for carbon substrates added to soil systems. These models are based on a first-order degradation reaction plus zero-order endogenous respiration. Microbial growth, if it occurs, can be either linear or exponential.

For the case with linear growth, which Brunner \& Focht (1984) found to best fit available soil data, the cumulative production of a metabolic product $\mathrm{P}$ (i.e. $\mathrm{CO}_{2}$ ) is expressed by

$$
\mathrm{P}=\mathrm{S}_{\mathrm{o}}\left(1-\mathrm{e}^{-\mathrm{k}_{1} \mathrm{t}-\left(\mathrm{k}_{2} \mathbf{t}^{2}\right) / 2}\right)+\mathrm{k}_{\mathrm{o}} \mathrm{t}
$$

where $\mathrm{t}$ represents incubation time, $\mathrm{S}_{\circ}$ is the amount of substrate mineralized to $\mathrm{CO}_{2}, \mathrm{k}_{1}$ is the first-order rate constant for degradation, $\mathrm{k}_{2}$ (units reciprocal time squared) describes the linear increase in degradation rate constant through growth, and $k_{o}$ is a zero-order rate constant describing endogenous mineralization (Brunner \& Focht, 1984; equation 12). In graphical terms, product concentration $P$ rises rapidly in the firstorder degradation reaction (rate constant $\mathrm{k}_{1}$ augmented linearly by $k_{2}$ ) to an inflection at approximately $\mathrm{S}_{\mathrm{o}}$. Any further increase in product concentration occurs through continued endogenous respiration $\left(\mathrm{k}_{\mathrm{o}}\right)$.

Equation 1 was fit to the ${ }^{14} \mathrm{C}$-EOC radiorespirometric data using the multivariant secant method in the least-squares Nonlinear Regression procedure (NLIN) by SAS Institute Inc., Cary, NC, USA. Time lags found in ${ }^{14} \mathrm{C}$-EOC evolution were considered artifacts of sample preparation (see Discussion) and were subtracted from incubation time values before curve-fitting. For each microcosm, total ${ }^{14} \mathrm{C}$-EOC utilization was calculated as ${ }^{14} \mathrm{C}$ respired plus ${ }^{14} \mathrm{C}$ assimilated at the end of incubation. Calculation of percent respiration of EOC was based on the amount of substrate mineralized in the first-order degradation reaction $\left(\mathrm{S}_{\mathrm{o}}\right)$ expressed as a percentage of total utilization. This percentage was frequently less than final respiration because of the contribution of a zero-order respiration component $\left(\mathrm{k}_{\mathrm{o}}\right)$ to the latter.

\section{Results}

On each sampling occasion, ${ }^{14} \mathrm{C}$-EOC remaining after incubation of the mixed planktonic community with $\mathrm{H}^{14} \mathrm{CO}_{3}$ was labile to further metabolism by lake microheterotrophs. The time-course of ${ }^{14} \mathrm{C}$-EOC mineralization was remarkably consistent for all respirometric assays (Fig. 1). After a lag period ( 0.75 to 3.5 days) with no ${ }^{14} \mathrm{CO}_{2}$ evolution, ${ }^{14} \mathrm{C}$-EOC mineralization proceeded with approximately first-order kinetics. The linear growth model (equation 1) provided an excellent fit for these ${ }^{14} \mathrm{CO}_{2}$ time-course data, with an average of $99 \%$ of total sum of squares attributed to the regression (range $96.5 \%$ to $99.9 \%$ ). An exponential growth model (Brunner \& Focht, 1984; equation 13), which required the fitting of five parameters, was also evaluated. The residual sum of squares was lowered in most cases by this

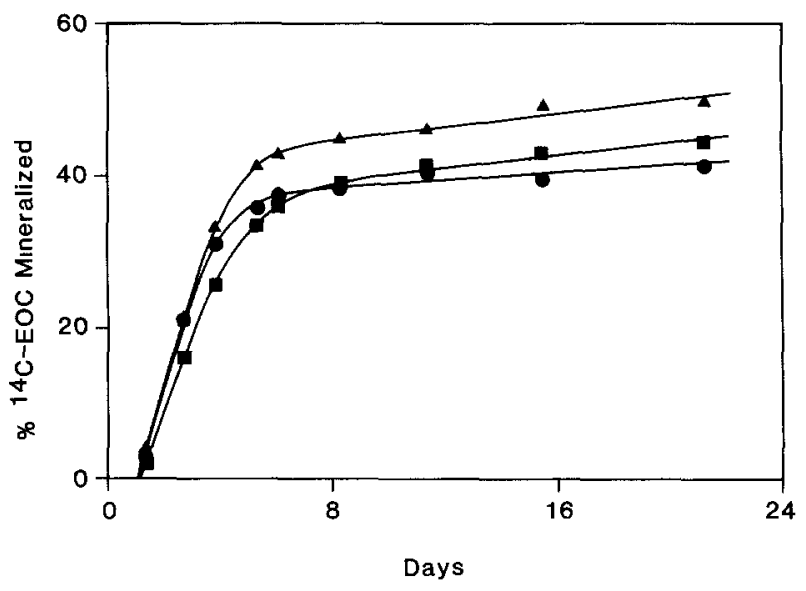

Fig. 1. Time-courses for cumulative mineralization of ${ }^{14} \mathrm{C}$ labelled residual algal products in vial microcosms following inoculation with lake heterotrophs. Three replicate vials from one assay occasion are shown. Lines represent non-linear least-squares fits of equation 1 for each vial. 
alternate model, but the reduction was modest, and the error in fitted parameter values was greatly increased. Of a total of $49{ }^{14} \mathrm{CO}_{2}$ timecourses, 35 could be fit by the linear growth model with a requirement for non-negative values as the only constraint on parameters. The remaining 14 data sets required further constraints; in most of these cases an upper limit was necessary for $\mathrm{k}_{2}$ to give biologically reasonable parameter estimates.

Reproducibility of parameter estimates from replicate vial microcosms was good. In 12 sets of replicate vials, average coefficients of variation were $23 \%$ for the mineralization rate constant $\left(\mathrm{k}_{1}\right)$ and $18 \%$ and $7 \%$ for ${ }^{14} \mathrm{C}$-EOC respiration $\left(\mathrm{S}_{\mathrm{o}}\right)$ and respiration plus assimilation, respectively. For 20 vials from 4 different occasions, ${ }^{14} \mathrm{C}$ remaining in the liquid phase at termination was measured to allow calculation of ${ }^{14} \mathrm{C}$ mass balance. Overall recovery of ${ }^{14} \mathrm{C}$ averaged $96 \%$ of that added initially as ${ }^{14} \mathrm{C}$-EOC substrate.

Total ${ }^{14} \mathrm{C}$ utilization (respiration + assimilation) amounted to $50 \%$ to $80 \%$ of added residual ${ }^{14} \mathrm{C}$-EOC on most occasions, although some lower values were found (Fig. 2A). This utilized EOC represented the portion of residual EOC which was labile to natural microheterotrophs over a long-term incubation. The rate constant for EOC mineralization showed a mode at 0.05 to $0.15 \mathrm{~d}^{-1}$ (rate of approximately $5 \%$ to $15 \%$ of the labile portion per day) with two higher and one lower value (Fig. 2B). A single value of 0.55 per day was recorded. Percent respiration of residual ${ }^{14} \mathrm{C}$-EOC ranged from $33 \%$ to $78 \%$ of gross uptake (Fig. 2C).

\section{Discussion}

Our primary objectives in investigating bacterial utilization of residual algal EOC were to determine 1) whether this organic carbon is metabolized by lake heterotrophs, 2) what portion is labile, and 3) with what conversion efficiency this carbon is utilized. The results of these assays, which spanned most of one ice-free season, are significant for quantitative study of organic carbon flux from phytoplankton to bacterioplankton.
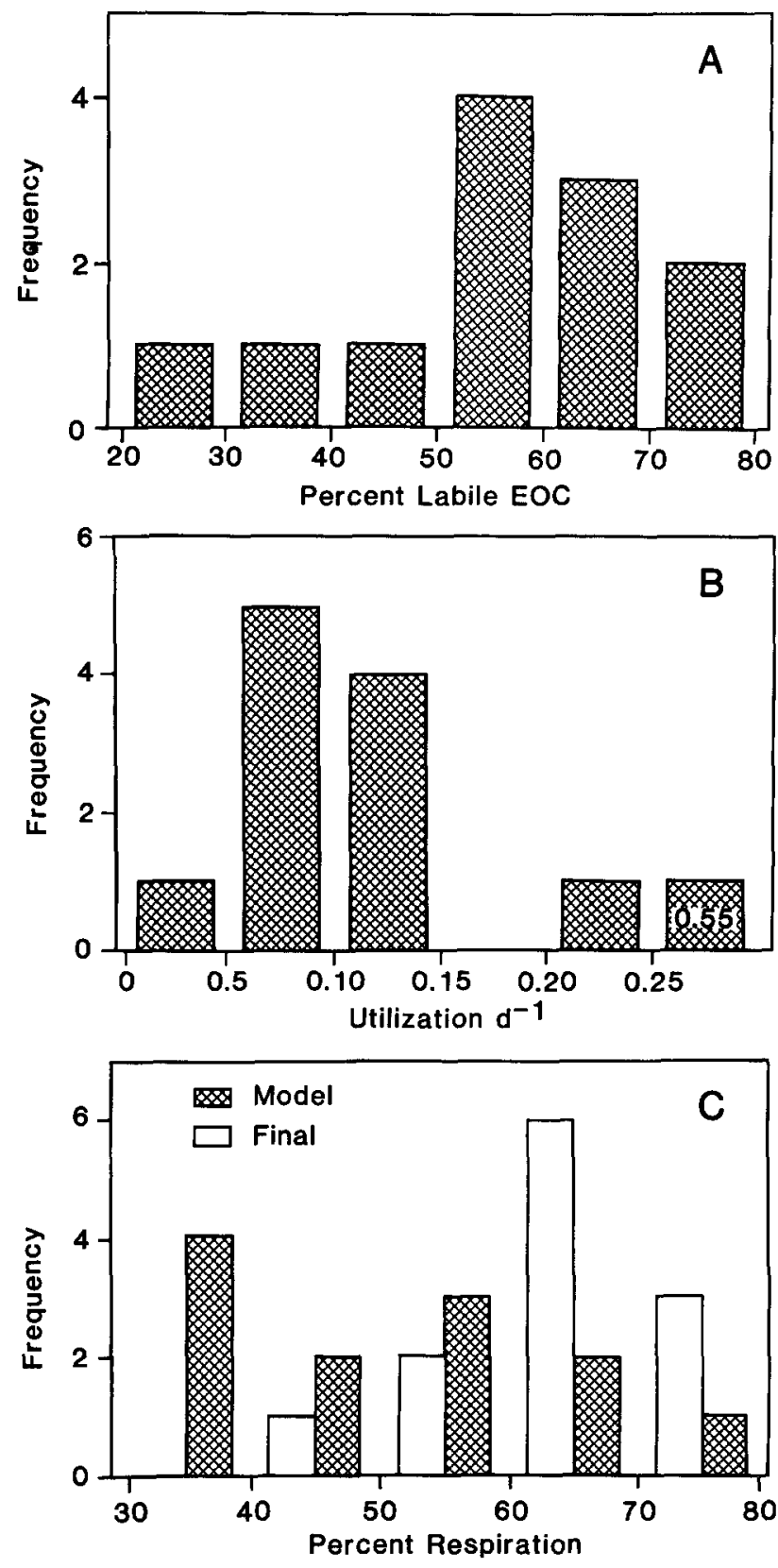

Fig. 2. Distribution of parameter values for utilization of residual algal EOC substrate by lake heterotrophs on 12 occasions, April to November.

A. Percent of residual EOC which was labile to heterotrophic utilization (respiration + assimilation).

B. First-order rate constant for EOC utilization $\left(k_{1}\right)$. A single high value $(0.55)$ is shown off scale.

C. Percent respiration of residual algal EOC. Model values are based on mineralization in the first-order degradation reaction $\left(\mathrm{S}_{\mathrm{o}}\right)$. Final values represent cumulative respiration through the entire incubation and include a zeroorder respiration component $\left(\mathbf{k}_{\mathrm{o}}\right)$. 
Residual labelled algal EOC after incubation of the mixed planktonic community with $\mathrm{H}^{14} \mathrm{CO}_{3}$ was susceptible to further long-term metabolism by lake heterotrophs. A seasonal average of $55 \%$ (range $29 \%$ to $76 \%$ ) of residual EOC was labile, and this slow carbon flux would be ignored by size-fractionation methodology commonly used to assay bacterial utilization of algal EOC. The algal EOC which is only slowly metabolized by bacterioplankton would tend to buffer the labile dissolved organic carbon pool and temporally uncouple bacterial and algal production dynamics. For example, peak summer bacterial production in Lake Michigan was postulated to be partly supported by EOC released during spring (Scavia and Laird, 1987). Slow turnover of a portion of algal EOC would dampen diel oscillations in bacterial productivity, which may contribute to the unpredictability reported for diel patterns (Riemann \& Søndergaard, 1984a; Fuhrman et al., 1985).

Depending on measurement occasion, between $33 \%$ and $78 \%$ (mean $50 \%$ ) of gross residual ${ }^{14} \mathrm{C}$-EOC uptake was respired (Fig. 2c). This range extends higher than most values reported for individual ${ }^{14} \mathrm{C}$-labelled organic compounds and short incubation periods (Hoppe, 1978) but is similar to the few comparable measurements performed with algal EOC substrates (e.g. Chrost \& Faust 1983; Jensen, 1983; Bell, 1984).

The yield of bacterial biomass carbon in utilization of algal EOC is an important variable in assessing the potential food-web significance of bacterial production (Williams, 1984; Ducklow et al., 1986). A carbon growth efficiency of $50 \%$ is frequently used in models of pelagic microbial food webs (Azam et al., 1983). Payne (1970) reviewed extensive data for bacterial cultures grown on defined carbon substrates and found $40 \%$ respiration to be the rule. Bjørnsen (1986) measured growth of marine bacteria cultured with natural seawater and found higher respiration with an average of about $80 \%$. His assays were based on direct carbon measurements, and he suggested that isotope tracer determinations underestimate respiration because of isotopic dilution in short incubations (e.g. King \& Berman,
1984). However, our data were obtained in extended incubations and demonstrate that lower respiration values are appropriate for heterogeneous algal EOC substrate and natural bacterial assemblages.

Percent respiration was calculated from the model parameter $\mathrm{S}_{o}$, which represented the amount of added ${ }^{14} \mathrm{C}$-EOC substrate mineralized in the first-order degradation reaction. This mineralization reflected the initial balance between assimilation and respiration during microbial utilization of EOC. In contrast, final ${ }^{14} \mathrm{CO}_{2}$ levels in each microcosm were determined by the first-order mineralization component plus a zero-order respiration rate $\mathrm{k}_{\mathrm{o}}$ (equation 1 ). In accordance with studies in soil systems (Brunner $\&$ Focht, 1984) we frequently found significant $k_{o}$ values in the microcosm time-courses (for example, two vials in Fig. 1). We interpreted this constant rate to represent endogenous respiration by bacteria or bacterivorous components of the microcosm biota. As such, it reflected the longterm respiratory loss of a heterotrophic community and not the initial balance between assimilation and respiration during EOC utilization.

The kinetics of degradation of carbon substrates by bacterial assemblages have been described in a variety of models in which degradation rate is a function of substrate concentration and microbial density (e.g. Simkins \& Alexander, 1984; Scow et al., 1986). Models differ in the explicit relationships used to relate substrate concentration to degradation rate (e.g. first-order, Michaelis-Menten, zero-order), and in assumptions about the occurrence of microbial growth and whether this growth takes place at the expense of the target substrate alone (Simkins \& Alexander, 1984; Scow et al., 1986).

A deterministic mixed-order model for mineralization of carbon substrates (Brunner \& Focht, 1984) provided an excellent empirical tool for analysis of mineralization of algal EOC by lake microheterotrophs and was chosen because of several favorable characteristics. This model included a zero-order term for endogenous respiration $\left(\mathrm{k}_{\mathrm{o}}\right)$, which was frequently seen as a linear ${ }^{14} \mathrm{CO}_{2}$ increase at the end of our time-courses (e.g. 
Fig. 1). Microbial growth was permitted in this model but was independent of target substrate depletion. This was a desirable condition since labelled residual EOC was present at low concentrations and was not necessarily the sole substrate for bacterial growth. Simpler model formulations (first-order, no growth; no endogenous mineralization) fit the time-course data much more poorly (not shown).

The assumption most likely to be violated in application of the mixed-order model to ${ }^{14} \mathrm{C}$-EOC mineralization is that of first-order uptake kinetics which requires that substrate concentration be much less than the half-saturation constant. In dealing with a heterogeneous mixture of compounds in the residual ${ }^{14} \mathrm{C}$-EOC substrate, analogies with single-substrate enzyme kinetics are only approximate (Bell, 1980). Bell (1984) estimated upper bounds of half-saturation constants for uptake of 19 to $125 \mu \mathrm{g} \mathrm{Cl}^{-1}$ when natural bacteria were exposed to algal EOC substrates. In the present study, initial residual ${ }^{14} \mathrm{C}$-EOC concentrations were approximately 2 to $10 \mu \mathrm{g} \mathrm{Cl}^{-1}$. We conclude that first-order uptake kinetics were probable but not certain.

Determination of rates of bacterial utilization of residual EOC was a secondary objective in this work, and the mineralization rate constant $\left(\mathrm{k}_{1}\right)$ was the parameter most likely to be affected by sample and inoculum manipulations or containment in the microcosm assay procedure. We concentrated microheterotrophs for inocula to approximate natural densities of bacteria so that initial EOC utilization rates in microcosms would reflect rates in situ. Utilization rates of residual EOC in the microcosms were $5 \%$ to $15 \%$ of the labile portion per day on most occasions (Fig. 2). No seasonal pattern was evident, and qualitative changes in EOC released by different algal communities is the probable explanation for the differences found (cf. Wolter, 1982). Residual EOC utilization rates in our assays were lower than most of the few values reported from similar measurements (Iturriaga \& Zsolnay, 1983; Chrost \& Faust, 1983). This may be due to the extended labelling period ( 6.0 to $8.5 \mathrm{~h}$ ) which we used to contrast EOC components subject to rapid versus slower heterotrophic turnover. Slowly metabolized ${ }^{14} \mathrm{C}$-EOC fractions would be enriched during longer labelling incubations. Additionally, molecular size distribution of ${ }^{14} \mathrm{C}-\mathrm{EOC}$ has been found to increase with labelling time (Søndergaard \& Schierup, 1982; Lancelot, 1984). Slower heterotrophic turnover of larger molecular size ${ }^{14} \mathrm{C}-\mathrm{EOC}$ (Jensen, 1983; Chrost \& Faust, 1983; Lancelot, 1984) would contribute to the low utilization rates which we observed.

Both initial mineralization rate constants, respiration and total utilization were independent of inoculum density in the range used for microcosms (Table 1). Other experiments showed that use of an inoculum concentrated on filters instead of by centrifugation or the addition of unlabeled organic substrates did not affect time-courses for ${ }^{14} \mathrm{C}$-EOC mineralization (not shown). These tests demonstrated that utilization kinetics for residual EOC were robust and reproducible and were not simple artifacts of experimental procedure. However, the possible consequences for mineralization kinetics of incubation in small-volume microcosms were not evaluated. The apparent insensitivity of residual ${ }^{14} \mathrm{C}$-EOC utilization to manipulations in bacterial density and, presumably, activity indicated the importance of other controlling factors. One such factor could have been a requirement for extracellular hydrolysis of EOC polymers before bacterial uptake (Lancelot, 1984), where this hydrolysis was the limiting step in utilization.

Table 1. Mean values for parameters of residual ${ }^{14} \mathrm{C}$-EOC utilization after inoculation of vial microcosms at two bacterial densities $(n=3)$. Initial densities were $17 \%$ and $51 \%$ of in situ values for $1 \mathrm{X}$ and $3 \mathrm{X}$ treatments, respectively. Means for each parameter are not significantly different (t-test, $\mathrm{p}>0.05$ ).

\begin{tabular}{llll}
\hline $\begin{array}{l}\text { Inoculum } \\
\text { density }\end{array}$ & $\begin{array}{l}\text { Mineralization } \\
\text { rate constant } \mathrm{k}_{1} \\
\left(\mathrm{~d}^{-1}\right)\end{array}$ & $\begin{array}{l}\text { Percent } \\
\text { respiration } \\
(\%)\end{array}$ & $\begin{array}{l}\text { Labile }{ }^{14} \mathrm{C}^{1} \\
(\mathrm{dpm})\end{array}$ \\
\hline $1 \mathrm{X}$ & 0.082 & 43 & 2697 \\
$3 \mathrm{X}$ & 0.097 & 37 & 2683 \\
\hline
\end{tabular}

1 Respiration plus assimilation. 
The second exponential term $\mathrm{k}_{2}$ was a measure of microbial growth in the model used to evaluate EOC mineralization kinetics (eq. 1). We did not monitor microbial growth in the vial microcosms, but a $3 \mathrm{X}$ increase in the initial inoculum density did not change the kinetics of ${ }^{14} \mathrm{C}$-EOC utilization (Table 1). Thus, while often significant in improving model fits, $\mathrm{k}_{2}$ terms for our microcosm timecourses did not originate from simple microbial growth as proposed for soil systems (Brunner \& Focht, 1984). Because of the long incubations which were necessary to describe these mineralization time-courses and the possibility of containment artifacts, we considered only the initial firstorder mineralization rate constant $\mathrm{k}_{1}$. Growth or other effects on mineralization kinetics over time as described by the $\mathrm{k}_{2}$ parameter were not considered because microbial growth in microcosms would not be expected to parallel that in the natural system.

A lag in initiation of ${ }^{14} \mathrm{CO}_{2}$ production (Fig. 1) was always observed in the microcosm assays for ${ }^{14} \mathrm{C}$-EOC utilization. The lag period did not result from damage to bacterial cells during inoculum preparation, since it was also present when test vials were inoculated with whole lake water. A lag was not characteristic for EOC substrate alone; similar patterns were found when ${ }^{14} \mathrm{C}$-glucose was added to vial systems on several occasions. This lag in ${ }^{14} \mathrm{CO}_{2}$ production is in sharp contrast to the immediate respiration usually seen when ${ }^{14} \mathrm{C}$-labelled substrates are added to natural waters (Hobbie \& Crawford, 1969; Bell, 1984).

We conclude that the lag observed in ${ }^{14} \mathrm{CO}_{2}$ evolution was an artifact which resulted from rigorous removal of $\mathrm{CO}_{2}$ from the substrate, the inoculum and the vial atmosphere as the microcosms were assembled. It has been shown that numerous aerobic heteterotrophic bacteria require a threshold environmental $\mathrm{CO}_{2}$ level for growth (Valley \& Rettger, 1927; Walker, 1932) and can be held in a lag phase if respiratory $\mathrm{CO}_{2}$ is continuously removed. The significant inverse relationship found between lag time and incubation temperature (Fig. 3) supports this explanation, because increased respiratory activity at higher temperature would reestablish external
$\mathrm{CO}_{2}$ levels more quickly. $\mathrm{CO}_{2}$ was removed to avoid possible lowering of counting efficiency by adsorption of extraneous $\mathrm{CO}_{2}$ on the inner vial wick (Coveney \& Wetzel, 1984). However, our experience suggested that $\mathrm{CO}_{2}$ at air equilibrium should be left in the substrate to avoid one cause of metabolic lag. The problem has not been described in other applications of double-vial radiorespirometry (Buddemeyer et al., 1978; McKinley et al., 1983), probably because $\mathrm{CO}_{2}$ was not rigorously removed and overall microbial respiratory activity was higher.

Seasonal patterns of EOC release and utilization by bacterioplankton in Lawrence Lake will be discussed in detail elsewhere. EOC release averaged about $20 \%$ of gross photosynthetic ${ }^{14} \mathrm{C}$ assimilation during the period considered here, which indicates a potentially important source of reduced carbon substrate to bacterioplankton. Over the ice-free season, long-term bacterial turnover of EOC was approximately equal in magnitude to that occurring by rapid uptake and assayed with size fractionation (data not shown). Consideration of long-term utilization of algal EOC in this system will double the estimated direct carbon flux from phytoplankton to bacterioplankton.

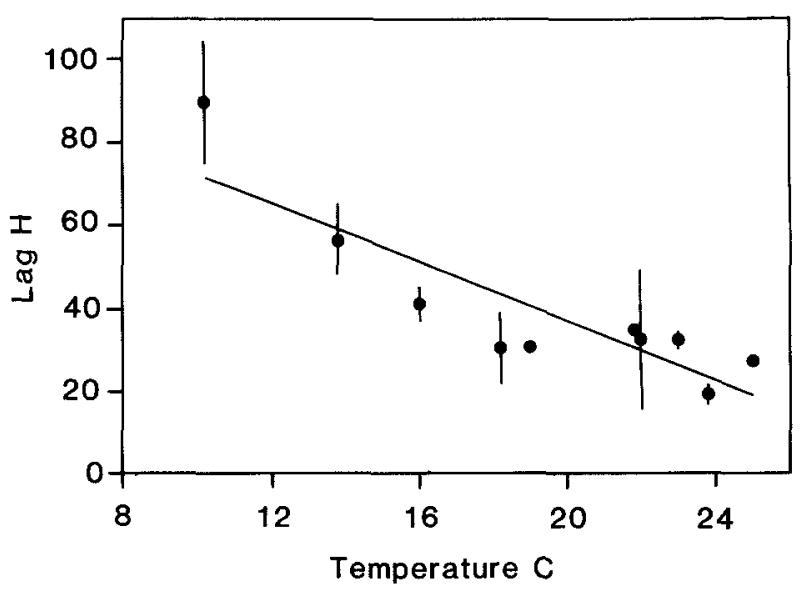

Fig. 3. Mean lag times ( \pm standard error if larger than symbol) for ${ }^{14} \mathrm{CO}_{2}$ evolution in vial microcosms as a function of incubation temperature. Measurements from two of the twelve occasions did not permit estimation of lag times because of overall low ${ }^{14} \mathrm{C}$ levels. The slope of the line is significant $(\mathrm{p}<0.001)$. 


\section{Acknowledgements}

Sandra Marsh assisted with the radiorespirometric assays, and Richard Losee commented on the manuscript. This work was supported by the National Science Foundation (BSR-8307716) and the U.S. Department of Energy (DE-ACO276EVO1599, COO-1599-304). The Swedish Natural Science Research Council (B-PH-3603-102) provided partial support for M.F.C.

\section{References}

Azam, F., T. Fenchel, J. G. Field, J. S. Gray, L. A. Meyer-Reil \& F. Thingstad, 1983. The ecological role of water-column microbes in the sea. Mar. Ecol. prog. Ser. 10: 257-263.

Bell, R. T. \& J. Kuparinen, 1984. Assessing phytoplankton and bacterioplankton production during early spring in Lake Erken, Sweden. Appl. envir. Microbiol. 48: 1221-1230.

Bell, W. H., 1980. Bacterial utilization of algal extracellular products. 1. The kinetic approach. Limnol. Oceanogr. 25: $1007-1020$.

Bell, W. H., 1984. Bacterial adaptation to low-nutrient conditions as studied with algal extracellular products. Microb. Ecol. 10: 217-230.

Berman, T. \& B. Kaplan, 1984. Diffusion chamber studies of carbon flux from living algae to heterotrophic bacteria. Hydrobiologia 108: 127-134.

Bjørnsen, P. K., 1986. Bacterioplankton growth yield in continuous seawater cultures. Mar. Ecol. prog. Ser. 30: 191-196.

Brock, T. D. \& J. Clyne, 1984. Significance of algal excretory products for growth of epilimnetic bacteria. Appl. envir. Microbiol. 47(4): 731-734.

Brunner, W. \& D. D. Focht, 1984. Deterministic three-halforder kinetic model for microbial degradation of added carbon substrates in soil. Appl envir. Microbiol. 47: 167-172.

Buddemeyer, E. U., G. M. Wells, R. Hutchinson, M. D. Cooper \& G. S. Johnston, 1978. Radiometric estimation of the replication time of bacteria in culture: An objective and precise approach to quantitative microbiology. J. Nucl. Med. 19: 619-625.

Chrost, R. J. \& M. A. Faust, 1983. Organic carbon release by phytoplankton: its composition and utilization by bacterioplankton. J. Plankton Res. 5: 477-493.

Cole, J. J., G. E. Likens \& D. L. Strayer, 1982. Photosynthetically produced dissolved organic carbon: An important carbon source for planktonic bacteria. Limnol. Oceanogr. 27: 1080-1090.

Coveney, M. F., 1982. Bacterial uptake of photosynthetic carbon from freshwater phytoplankton. Oikos 38: 8-20.
Coveney, M. F. \& R. G. Wetzel, 1984. Improved double-vial radiorespirometric technique for mineralization of ${ }^{14} \mathrm{C}$ labeled substrates. Appl. envir. Microbiol. 47: 1154-1157.

Ducklow, H. W., D. A. Purdie, P. J. LeB. Williams \& J. M. Davies, 1986. Bacterioplankton: a sink for carbon in a coastal marine plankton community. Science 232: 865-867.

Fuhrman, J. A., R. W. Eppley, Å. Hagström \& F. Azam, 1985. Diel variations in bacterioplankton, phytoplankton, and related parameters in the Southern California Bight. Mar. Ecol. prog. Ser. 27: 9-20.

Hobbie, J. E. \& C. C. Crawford, 1969. Respiration corrections for bacterial uptake of dissolved organic compounds in natural waters. Limnol. Oceanogr. 14: 528-532.

Hoppe, H.-G., 1978. Relations between active bacteria and heterotrophic potential in the sea. Neth. J. Sea Res. 12: 78-98.

Iturriaga R. \& H.-G. Hoppe, 1977. Observations of heterotrophic activity on photoassimilated organic matter. Mar. Biol. 40: 101-108.

Iturriaga, R. \& A. Zsolnay, 1983. Heterotrophic uptake and transformation of phytoplankton extracellular products. Bot. Mar. 26: 375-381.

Jensen, L. M., 1983. Phytoplankton release of extracellular organic carbon, molecular weight composition, and bacterial assimilation. Mar. Ecol. prog. Ser. 11: 39-48.

Jensen, L. M., N. O. G. Jørgensen \& M. Søndergaard, 1985. Specific activity. Significance in estimating release rates of extracellular dissolved organic carbon (EOC) by algae. Verh. int. Ver. Limnol. 22: 2893-2897.

Kato, K. \& H.-H, Stabel, 1984. Studies on the carbon flux from phyto- to bacterioplankton communities in Lake Constance. Arch. Hydrobiol. 102: 177-192.

King, G. M. \& T. Berman, 1984. Potential effects of isotopic dilution on apparent respiration in ${ }^{14} \mathrm{C}$ heterotrophy experiments. Mar. Ecol. prog. Ser. 19: 175-180.

Lancelot, C., 1984. Extracellular release of small and large molecules by phytoplankton in the Southern Bight of the North Sea. Estuarine, Coastal and Shelf Science 18: 65-77.

Larsson, U. \& $\AA$. Hagstrom, 1982. Fractionated phytoplankton primary production, exudate release and bacterial production in a Baltic eutrophication gradient. Mar. Biol. 67: $57-70$.

Lovell, C. R. \& A. Konopka, 1985. Excretion of photosynthetically fixed organic carbon by metalimnetic phytoplankton. Microb. Ecol. 11: 1-9.

McKinley, V. L., T.W. Federle \& J. R. Vestal, 1983. Improvements in and environmental applications of double-vial radiorespirometry for the study of microbial mineralization. Appl. envir. Microbiol. 45: 255-259.

Payne, W. J., 1970. Energy yields and growth of heterotrophs. Ann. Rev. Microbiol. 24: 17-52.

Riemann, B. \& M. Søndergaard, 1984a. Measurements of diel rates of bacterial secondary production in aquatic environments. Appl. envir. Microbiol 47: 632-638. 
Riemann, B. \& M. Søndergaard, 1984b. Bacterial growth in relation to phytoplankton primary production and extracellular release of organic carbon. In J. E. Hobbie \& P. J. leB. Williams (eds), Heterotrophic Activity in the Sea. Plenum press, N.Y.: 233-248.

Riemann, B., M. Søndergaard, H.-H. Schierup, S. Bosselmann, G. Christensen, J. Hansen \& B. Nielsen, 1982. Carbon metabolism during a spring diatom bloom in the eutrophic Lake Mossø. Int. Revue ges. Hydrobiol. 67: 145-185.

Scavia, D. \& G. A. Laird, 1987. Bacterioplankton in Lake Michigan: dynamics, controls, and significance to carbon flux. Limnol. Oceanogr. 32: 1017-1033.

Scow, K. M., S. Simkins \& M. Alexander, 1986. Kinetics of mineralization of organic compounds at low concentrations in soil. Appl. envir. Microbiol. 51: 1028-1035.

Simkins, S. \& M. Alexander, 1984. Models for mineralization kinetics with the variables of substrate concentration and population density. Appl. envir. Microbiol. 47: 1299-1306.

Søndergaard, M. \& H.-H. Schierup, 1982. Release of extra- cellular organic carbon during a diatom bloom in Lake Mossø: molecular weight fractionation. Freshwat. Biol. 12: 313-320.

Storch, T. A. \& G. W. Saunders, 1978. Phytoplankton extracellular release and its relation to the seasonal cycle of dissolved organic carbon in a eutrophic lake. Limnol. Oceanogr. 23: 112-119.

Valley, G. \& L.F. Rettger, 1927. The influence of carbon dioxide on bacteria. J. Bact. 14: 101-137.

Walker, H. H., 1932. Carbon dioxide as a factor affecting lag in bacterial growth. Science 76: 602-604.

Wetzel, R. G., 1983. Limnology. 2nd Ed. W. B. Saunders Co. $860 \mathrm{p}$.

Williams, P. J. LeB., 1984. Bacterial production in the marine food chain: the emperor's new suit of clothes? In Fasham, M. J. R. (Ed.), Flows of Energy and Materials in Marine Ecosystems: Theory and Practice. Plenum Press, N.Y.: 271-299.

Wolter, K., 1982. Bacterial incorporation of organic substances released by natural phytoplankton populations. Mar. Ecol. prog. Ser. 7: 287-295. 